\title{
Crystal Structure of $\mu$-Phenoxo- $\mu$-benzoate-bridged Dinuclear Fe(II) Complex with a Dinucleating Ligand Having a Sterically Bulky Imidazolyl Group
}

\author{
Yuichi YASUdA, ${ }^{* 1}$ Hideki FurUTACHI, ${ }^{* 1 \dagger}$ Yosuke HaYaSHI, ${ }^{* 1}$ Kana IsHIZAKI, ${ }^{* 1}$ Shuhei FuJINAMI, ${ }^{* 1}$ \\ Shigehisa AKInE, ${ }^{* 1, * 2}$ Masatatsu SuzukI, ${ }^{* 1}$ Shigenori Nagatomo, ${ }^{* 3}$ and Teizo KITAgawa $* 4$ \\ *1 Department of Chemistry, Division of Material Sciences, Graduate School of Natural Science and Technology, \\ Kanazawa University, Kakuma-machi, Kanazawa 920-1192, Japan \\ *2 Nano Life Science Institute (WPI-NanoLSI), Kanazawa University, Kakuma-machi, Kanazawa 920-1192, Japan \\ *3 Department of Chemistry, Faculty of Pure and Applied Sciences, University of Tsukuba, Tsukuba, \\ Ibaraki 305-8571, Japan \\ *4 Picobiology Institute, Graduate School of Life Science, University of Hyogo, Ako-gun, Hyogo 678-1297, Japan
}

\begin{abstract}
The structure of the dinuclear Fe(II) complex $\left[\mathrm{Fe}_{2}\left(\mathrm{Ph}\right.\right.$-bimp) $\left.\left(\mathrm{PhCO}_{2}\right)\left(\mathrm{CH}_{3} \mathrm{CN}\right)\right]\left(\mathrm{BF}_{4}\right)_{2} \cdot 2 \mathrm{CH}_{3} \mathrm{CN} \cdot 3 \mathrm{CH}_{3} \mathrm{CH}_{2} \mathrm{OH}$ (1) was determined by X-ray crystallography, where Ph-bimp is 2,6-bis[bis\{2-(1-methyl-4,5-diphenylimidazolyl)methyl\}aminomethyl]-4-methylpenolate. The compound crystallizes in a monoclinic space group $C c$ with $a=15.5690(10)$, $b=23.8260(8), c=24.821(1) \AA, \beta=95.3460(3)^{\circ}, Z=4, V=9167.2(10) \AA^{3}$. The $R 1[I>2 \sigma(I)]$ and $w R 2$ (all data) values are 0.0336 and 0.0850 , respectively, for all 16812 independent reflections. The complex has a $\mu$-phenoxo- $\mu$-benzoatebridged diiron(II) core structure.
\end{abstract}

(Received October 15, 2018; Accepted December 2, 2018; Published on web March 10, 2019)

The end-off type compartmental ligands, having a phenolic and alcoholic oxygen as an endogenous bridge, have been used for modeling bimetallic active sites of metalloprotains, ${ }^{1-4}$ such as hemerythrin $(\mathrm{Hr})^{5}$ and methane monooxygenase (MMO). ${ }^{6} \mathrm{We}$ have demonstrated that the thermal stability of ( $\mu$-peroxo) diiron(III) complexes and the oxygenation-deoxygenation reversibility are highly dependent on the nature of the end-off type compartmental ligands. ${ }^{4,7-11}$ Previously, we reported the crystal structure of a $\left(\mu\right.$-peroxo)diiron(III) complex, $\left[\mathrm{Fe}_{2}(\mathrm{Ph}\right.$ bimp) $\left.\left(\mathrm{PhCO}_{2}\right)\left(\mathrm{O}_{2}\right)\right]^{2+}$, with a dinucleating ligand (Ph-bimp) bearing a sterically bulky imidazolyl group,${ }^{8}$ which was obtained in a reversible reaction of the corresponding diiron(II) precursor complex, $\left[\mathrm{Fe}_{2}(\mathrm{Ph}\right.$-bimp $\left.)\left(\mathrm{PhCO}_{2}\right)\right]\left(\mathrm{BF}_{4}\right)_{2} \cdot 3 \mathrm{H}_{2} \mathrm{O}$, with dioxygen in acetonitrile at ambient temperature. In this paper, we report details of the crystal structure of the diiron(II) precursor complex $\left[\mathrm{Fe}_{2}(\mathrm{Ph}\right.$-bimp $\left.)\left(\mathrm{PhCO}_{2}\right)\left(\mathrm{CH}_{3} \mathrm{CN}\right)\right]\left(\mathrm{BF}_{4}\right)_{2} \cdot 2 \mathrm{CH}_{3} \mathrm{CN} \cdot 3 \mathrm{CH}_{3} \mathrm{CH}_{2} \mathrm{OH}$ (1) (Fig. 1).

A single crystal of $\left[\mathrm{Fe}_{2}(\mathrm{Ph}\right.$-bimp $\left.)\left(\mathrm{PhCO}_{2}\right)\left(\mathrm{CH}_{3} \mathrm{CN}\right)\right]\left(\mathrm{BF}_{4}\right)_{2}$. $2 \mathrm{CH}_{3} \mathrm{CN} \cdot 3 \mathrm{CH}_{3} \mathrm{CH}_{2} \mathrm{OH}$ (1) suitable for X-ray crystallography was obtained by recrystallization of $\left[\mathrm{Fe}_{2}(\mathrm{Ph}\right.$-bimp $\left.)\left(\mathrm{PhCO}_{2}\right)\right]$ $\left(\mathrm{BF}_{4}\right)_{2} \cdot 3 \mathrm{H}_{2} \mathrm{O}^{8}$ from a mixture of acetonitrile/ethanol at ambient temperature under $\mathrm{N}_{2}$. It was picked up on a hand-made cold copper plate mounted inside a liquid $\mathrm{N}_{2}$ Dewar vessel and mounted on a glass rod at $-80^{\circ} \mathrm{C}$. X-ray diffraction measurements were made on a Rigaku CCD Mercury diffractometer with graphite monochromated Mo $K \alpha$ radiation at $108 \mathrm{~K}$. The structure was solved by a direct method (SIR 92) ${ }^{12}$ and expanded using a Fourier technique. The structure was refined by a fullmatrix least-squares method by using SHELXL 2014 ${ }^{13}$ (Yadokari-XG). ${ }^{14}$ All non-hydrogen atoms were refined with anisotropic displacement parameters (ADP) and all hydrogen

$\dagger$ To whom correspondence should be addressed.

E-mail: h-furutachi@se.kanazawa-u.ac.jp atoms were included using a riding model. The occupancy factors were also refined for the two $\mathrm{BF}_{4}{ }^{-}$anions, one acetonitrile molecule, and three ethanol molecules, which were disordered over two or three orientations. Distance/ADP restraints were applied to the disordered atoms in the anions and solvents. The crystal data is summarized in Table 1 .

The molecular structure of complex cation $\left[\mathrm{Fe}_{2}(\mathrm{Ph}-\right.$ bimp $)-$ $\left.\left(\mathrm{PhCO}_{2}\right)\left(\mathrm{CH}_{3} \mathrm{CN}\right)\right]^{2+}$ of $\mathbf{1}$ is shown in Fig. 2. Selected bond distances $(\AA)$ and angles $\left(^{\circ}\right)$ are given in Table 2. The diiron(II) center is doubly bridged by phenoxide oxygen of Ph-bimp and benzoate oxygens, as found for closely related diiron(II) complexes: $\left[\mathrm{Fe}_{2}(\mathrm{Ph}-\mathrm{tidp})\left(\mathrm{PhCO}_{2}\right)\right]^{2+} \quad(\mathbf{2}) \quad\left(\mathrm{Ph}\right.$-tidp $=N, N, N^{\prime}, N^{\prime}$ tetrakis(1-methyl-4,5-diphenyl-2-imidazolyl)methyl-1,3-diamino2-propanolate $),{ }^{9} \quad\left[\mathrm{Fe}_{2}\left(\mathrm{~L}^{\mathrm{Ph} 4}\right)\left(\mathrm{PhCO}_{2}\right)\right]^{2+} \quad$ (3) $\quad\left(\mathrm{L}^{\mathrm{Ph} 4}=N, N, N^{\prime}, N^{\prime}-\right.$ tetrakis(1-methyl-2-phenyl-4-imidazolyl)methyl-1,3-diamino2-propanolate), ${ }^{10}$ and $\left[\mathrm{Fe}_{2}(N \text {-Et-HPTB })\left(\mathrm{PhCO}_{2}\right)\right]^{2+}$ (4) $(N$-EtHPTB $=N, N, N^{\prime}, N^{\prime}$-tetrakis(1-ethyl-2-benzimidazolyl)methyl1,3-diamino-2-propanolate). ${ }^{15}$ The two iron atoms in $\mathbf{1}$ have different coordination geometries. The five-coordinate iron

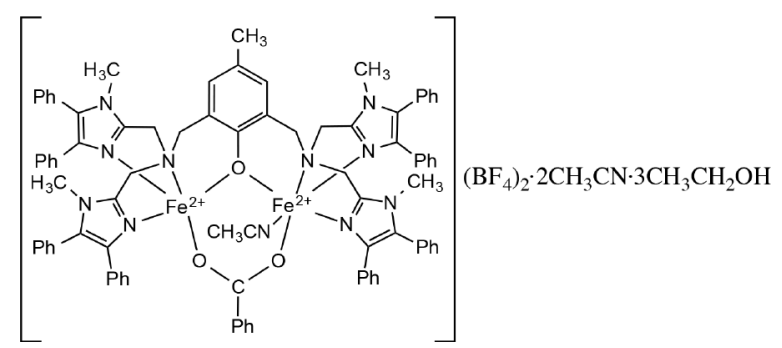

Fig. 1 Chemical diagram of $\left[\mathrm{Fe}_{2}(\mathrm{Ph}-\right.$ bimp $\left.)\left(\mathrm{PhCO}_{2}\right)\left(\mathrm{CH}_{3} \mathrm{CN}\right)\right]$ $\left(\mathrm{BF}_{4}\right)_{2} \cdot 2 \mathrm{CH}_{3} \mathrm{CN} \cdot 3 \mathrm{CH}_{3} \mathrm{CH}_{2} \mathrm{OH}(\mathbf{1})$. 
Table 1 Crystal and experimental data

Chemical formula: $\mathrm{C}_{96} \mathrm{H}_{101} \mathrm{~B}_{2} \mathrm{~F}_{8} \mathrm{Fe}_{2} \mathrm{~N}_{13} \mathrm{O}_{6}$

Formula weight $=1818.21$

$T=108 \mathrm{~K}$

Crystal system: monoclinic Space group: $C c$

$a=15.5690(10) \AA$

$b=23.8260(8) \AA$

$c=24.821(2) \AA$

$V=9167.2(10) \AA^{3}$

$D_{\mathrm{x}}=1.317 \mathrm{~g} / \mathrm{cm}^{3}$

Radiation: Mo $K \alpha(\lambda=0.71073 \AA)$

$\mu($ Mo $K \alpha)=3.94 \mathrm{~cm}^{-1}$

$F\left(\begin{array}{lll}0 & 0 & 0\end{array}\right)=3800$

Crystal size $=0.5 \times 0.3 \times 0.3 \mathrm{~mm}^{3}$

No. of reflections collected $=42650$

No. of independent reflections $=16812$

$\theta$ range for data collection $=2.362$ to $27.484^{\circ}$

Data/Restraints/Parameters $=16812 / 623 / 1482$

Goodness-of-fit on $F^{2}=1.029$

Flack parameter $=0.007(4)$

$R$ indices $[I>2 \sigma(I)]: R 1=0.0336, w R 2=0.0825$

$R$ indices (all data): $R 1=0.0367, w R 2=0.0850$

$(\Delta / \sigma)_{\max }=0.001$

$(\Delta \rho)_{\max }=0.502 \mathrm{e}^{-3}(\Delta \rho)_{\min }=-0.312 \mathrm{e}^{-3}$

Measurement: Rigaku CCD Mercury Diffractometer

Data collection \& cell refinement program: CrystalClear

Structure solving program: SIR 92

Structure determination: SHELXL 2014

Refinement: full-matrix least squares against $F^{2}$

CCDC deposition number: CCDC 1872404

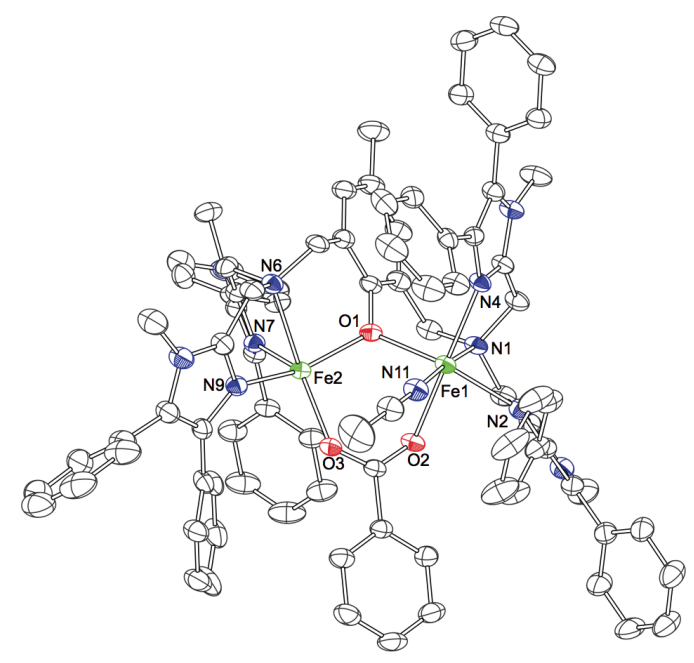

Fig. 2 ORTEP drawing of a complex cation, $\left[\mathrm{Fe}_{2}(\mathrm{Ph}\right.$-bimp $)\left(\mathrm{PhCO}_{2}\right)$ $\left.\left(\mathrm{CH}_{3} \mathrm{CN}\right)\right]^{2+}$, of $\mathbf{1}$, showing $50 \%$ probability ellipsoids. The hydrogen atoms are omitted for clarity.

atom $(\mathrm{Fe} 2)$ has a square-pyramidal structure $(\tau=0.08)^{16}$ with the nitrogen atom (N7) of Ph-bimp at the apex. The sixcoordinate iron atom (Fe1) contains an additional coordinated acetonitrile molecule to form a distorted octahedral structure with an $\mathrm{N}_{4} \mathrm{O}_{2}$ donor set. Bridging benzoate coordinates trans to the tertiary amine nitrogen atom of Ph-bimp in $\mathrm{Fe} 2$, whereas trans to the imidazolyl nitrogen atom of Ph-bimp in Fe1. Unlike $\mathbf{1}$, each iron center in $\mathbf{2 - \mathbf { 4 }}$ has a five-coordinate structure and bridging benzoate coordinates trans to the tertiary amine nitrogen atoms of dinucleating ligands. The Fe-ligand bond
Table 2 Selected bond distances $(\AA)$ and angles $\left({ }^{\circ}\right)$

\begin{tabular}{llll}
\hline $\mathrm{Fe} 1-\mathrm{O} 1$ & $2.043(2)$ & $\mathrm{Fe} 2-\mathrm{O} 1$ & $2.0160(19)$ \\
$\mathrm{Fe} 1-\mathrm{O} 2$ & $2.1955(19)$ & $\mathrm{Fe} 2-\mathrm{O} 3$ & $2.017(2)$ \\
$\mathrm{Fe} 1-\mathrm{N} 1$ & $2.260(2)$ & $\mathrm{Fe} 2-\mathrm{N} 6$ & $2.329(2)$ \\
$\mathrm{Fe} 1-\mathrm{N} 2$ & $2.126(3)$ & $\mathrm{Fe} 2-\mathrm{N} 7$ & $2.118(2)$ \\
$\mathrm{Fe} 1-\mathrm{N} 4$ & $2.194(2)$ & $\mathrm{Fe} 2-\mathrm{N} 9$ & $2.117(2)$ \\
$\mathrm{Fe} 1-\mathrm{N} 11$ & $2.137(3)$ & $\mathrm{Fe} 1 \cdots \mathrm{Fe} 2$ & $3.5350(6)$ \\
& & & \\
$\mathrm{Fe} 1-\mathrm{O} 1-\mathrm{Fe} 2$ & $121.10(9)$ & & \\
\hline
\end{tabular}

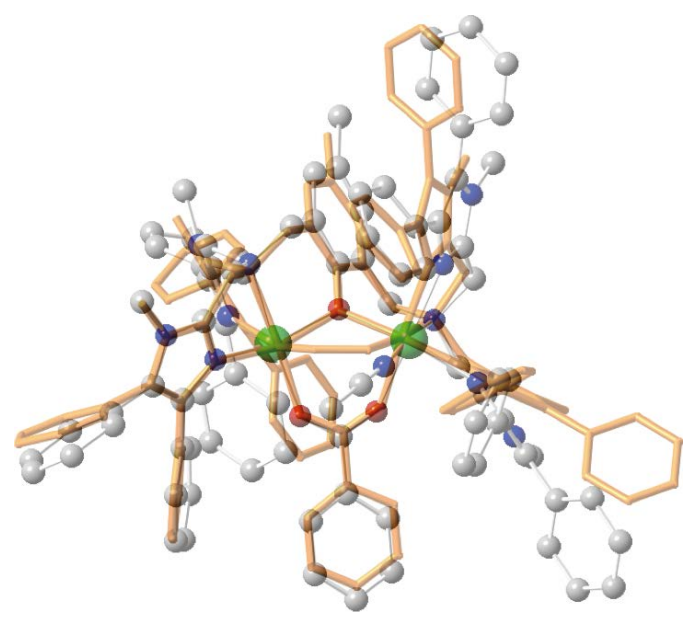

Fig. 3 Overlays of $\left[\mathrm{Fe}_{2}(\mathrm{Ph} \text {-bimp })\left(\mathrm{PhCO}_{2}\right)\left(\mathrm{CH}_{3} \mathrm{CN}\right)\right]^{2+}$ (ball-andstick) and $\left[\mathrm{Fe}_{2}(\mathrm{Ph} \text {-bimp })\left(\mathrm{PhCO}_{2}\right)\left(\mathrm{O}_{2}\right)\right]^{2+}$ (orange tube).

distances for $\mathbf{1}$ are characteristic of high spin $\mathrm{Fe}$ (II) complexes. ${ }^{4,7,9,10,15}$ The average Fe-N(imidazole) bond distance of $\mathbf{1}$ is $2.14 \AA$ is substantially longer than the average $\mathrm{Fe}$ $\mathrm{N}$ (benzimidazole) bond distance of $\mathbf{4}(2.07 \AA) .{ }^{15}$ The elongation in $\mathbf{1}$ is possibly due to unfavorable steric interactions among phenyl groups of $\mathrm{Ph}$-bimp, the bridging benzoate and the acetonitrile molecule (Fig. 2 and Figs. S2 - S3 (Supporting Information)). A similar observation was made for $2(2.12 \AA)^{9}$ and $3(2.12 \AA),{ }^{10}$ which have also sterically bulky phenyl groups. A comparison of the molecular structure of deoxy-form $\mathbf{1}$ and oxy-form $\left[\mathrm{Fe}_{2}(\mathrm{Ph}-\text { bimp })\left(\mathrm{PhCO}_{2}\right)\left(\mathrm{O}_{2}\right)\right]^{2+}$ (Fig. 3 and Figs. S2 - S3, and Table S1 (Supporting Information)) provides some suggestive information concerning the dioxygen affinity and the reversible oxygenation. The structure around two iron atoms in both forms are almost superimposed (Fig. 3), indicating that deoxyform 1 has a suitable dioxygen binding site on the diiron center in a $\mu$-1,2-peroxo fashion. Furthermore, the dioxygen binding site is in a hydrophobic pocket surrounded by phenyl groups of Ph-bimp (Fig. S3). This stereochemistry provided by the 2,6-bis(aminomethyl)phenolate bridging skeleton seems to be responsible for the high dioxygen affinity and thermal stability compared with that provided by 1,3-diamino-2-propanolate skeleton. ${ }^{4}$ The oxygenation of $\mathbf{1}$ to $\left[\mathrm{Fe}_{2}(\mathrm{Ph}\right.$-bimp $)\left(\mathrm{PhCO}_{2}\right)$ $\left.\left(\mathrm{O}_{2}\right)\right]^{2+}$ results in a closing of the $\mathrm{Fe}-\mathrm{O}$ (phenolate)-Fe angle from $121.10(9)^{\circ}$ to $111.7(2)^{\circ}$ and a shortening the $\mathrm{Fe} \ldots \mathrm{Fe}$ distance

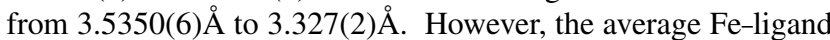
(Fe-N(tertiary amine), Fe-N(imidazole), and Fe-O(phenolate), except for $\mathrm{Fe}-\mathrm{O}$ (benzoate)) bond distances for $\mathbf{1}$ are comparable to those for $\left[\mathrm{Fe}_{2}(\mathrm{Ph} \text {-bimp })\left(\mathrm{PhCO}_{2}\right)\left(\mathrm{O}_{2}\right)\right]^{2+}$ (Table S1), indicating that $\mathrm{Ph}$-bimp stabilizes the $\mathrm{Fe}$ (II) oxidation state, which would facilitate the reversible oxygenation. The resonance Raman 
spectrum of $\left[\mathrm{Fe}_{2}(\mathrm{Ph} \text {-bimp })\left(\mathrm{PhCO}_{2}\right)\left(\mathrm{O}_{2}\right)\right]^{2+}$ showed an isotope sensitive band at $874 \mathrm{~cm}^{-1}\left({ }^{16-18} \Delta=49 \mathrm{~cm}^{-1}\right)$ in $\mathrm{CH}_{2} \mathrm{Cl}_{2}$ at $-90^{\circ} \mathrm{C}$ (Fig. S4, Supporting Information), which can be assigned to the $v(\mathrm{O}-\mathrm{O})$ vibration, ${ }^{1,3,4}$ which was not detected in a previous study. ${ }^{8}$

\section{Acknowledgements}

This work was supported by Grants-in-Aid for Scientific Research from the Ministry of Education, Culture, Sports, Science and Technology, Japan, and the Kanazawa University SAKIGAKE Project.

\section{Supporting Information}

A cif format file, Table S1, and Figs. S1 - S4. These materials are available free of charge on the Web at http://www.jsac.or.jp/ xraystruct/.

\section{References}

1. A. J. Jasniewski and L. Que Jr., Chem. Rev., 2018, 118 , 2554.

2. A. L. Gavrilova and B. Bosnich, Chem. Rev., 2004, 104, 349.

3. E. Y. Tshuva and S. J. Lippard, Chem. Rev., 2004, 104, 987.

4. M. Suzuki, H. Furutachi, and H. Okawa, Coord. Chem. Rev., 2000, 200-202, 105.
5. R. E. Stenkamp, Chem. Rev., 1994, 94, 715.

6. B. J. Wallar and J. D. Lipscomb, Chem. Rev., 1996, 96, 2625.

7. Y. Hayashi, T. Kayatani, H. Sugimoto, M. Suzuki, K. Inomata, A. Uehara, Y. Mizutani, T. Kitagawa, and Y. Maeda, J. Am. Chem. Soc., 1995, 117, 11220.

8. T. Ookubo, H. Sugimoto, T. Nagayama, H. Masuda, T. Sato, K. Tanaka, Y. Maeda, H. Okawa, Y. Hayashi, A. Uehara, and M. Suzuki, J. Am. Chem. Soc., 1996, 118, 701.

9. H. Sugimoto, T. Nagayama, S. Maruyama, S. Fujinami, Y. Yasuda, M. Suzuki, and A. Uehara, Bull. Chem. Soc. Jpn., 1998, 71, 2267.

10. M. Yamashita, H. Furutachi, T. Tosha, S. Fujinami, W. Saito, Y. Maeda, K. Takahashi, K. Tanaka, T. Kitagawa, and M. Suzuki, J. Am. Chem. Soc., 2007, 129, 2.

11. M. Sekino, H. Furutachi, R. Tojo, A. Hishi, H. Kajikawa, T. Suzuki, K. Suzuki, S. Fujinami, S. Akine, Y. Sakata, T. Ohta, S. Hayami, and M. Suzuki, Chem. Commun., 2017, 53,8838

12. A. Altomare, G. Cascarano, C. Giacovazzo, A. Guagliardi, M. C. Burla, G. Polidori, and M. Camalli, J. Appl. Crystallogr., 1994, 27, 435.

13. G. M. Sheldrick, Acta Crystallogr., 2008, A64, 112.

14. C. Kabuto, S. Akine, T. Nemoto, and E. Kwon, J. Cryst. Soc. Jpn., 2009, 51, 218.

15. Y. Dong, S. Ménage, B. A. Brennan, T. E. Elgren, H. G. Jang, L. L. Peace, and L. Que Jr., J. Am. Chem. Soc., 1993, $115,1851$.

16. A. W. Addison, T. N. Rao, J. Reedijk, J. van. Rijn, and G. C. Verschoor, J. Chem. Soc., Dalton Trans., 1984, 1349. 